\title{
ANALYSIS OF THE UTILIZATION OF E-LEARNING BY LECTURERS AT PANCA SAKTI BEKASI UNIVERSITY
}

\author{
Rita Aryani and Leroy Holman Siahaan \\ Universitas Panca Sakti, Bekasi, Jl. Raya Hankam No.54, Jatirahayu, Pondok Melati, Kota Bekasi, \\ Jawa Barat, 17414 \\ E-mail: ritaar1757@gmail.com; leroyholmansiahaan@gmail.com
}

\begin{abstract}
This study aims to describe qualitatively about e-learning management in the current Covid-19 pandemic era. This research is a descriptive qualitative study that aims to define and describe phenomena that appear natural or artificial, focusing more on examining the character, quality, and phenomenon. Besides, the e-learning approach is an approach using technology distance learning. The e-learning utilization that is arranged using an electronic internet system that supports learning activities. The method used in this research is qualitative with descriptive analysis. Research subjects are Informantss who provide research data through interviews, observation, and documents. The Informantss in this study were lecturers at Panca Sakti Bekasi University. The Informantss were determined by purposive sampling technique. At the same time, the data analysis used in this research is descriptive. This research results in the finding that lecturers have carried out web e-learning with Moodle and face-to-face with zoom or google meet in managing learning during the Covid-19 pandemic. as numerous as $80 \%$ of speakers expressed that they utilized zoom, this was on the grounds that it was simpler to apply it straightforwardly, like instructing up close and personal classes. At that point, as numerous as 55\% of Google Meet clients, the instructor expressed that Google Meet is not difficult to actualize on the grounds that the video is straightforwardly associated on the off chance that you as of now have a Google Mail account straightforwardly. Lastly, as numerous as $85 \%$ of teachers use Moodle, on the grounds that Moodle gives more highlights to learning exercises.
\end{abstract}

Keywords: E-Learning; Google Meet; Moodle; Zoom

\section{ANALISIS PEMANFAATAN MEDIA E-LEARNING OLEH DOSEN UNIVERSITAS PANCA SAKTI BEKASI}

\begin{abstract}
ABSTRAK. Penelitian ini bertujuan untuk mendeskripsikan secara kuantitatif tentang manajemen pembelajaran dengan pendekatan e-learning atau pembelajaran campuran di era pandemi Covid-19 saat ini. Penelitian ini merupakan penelitian kualitatif deskriptif yang bertujuan untuk mendefinisikan dan mendeskripsikan fenomena yang tampak alami atau artifisial yang lebih menitikberatkan pada pengkajian karakter, dan kualitas, dan fenoma kejadian. Selanjutnya, pendekatan e-learning merupakan pendekatan yang menggunakan teknologi untuk pembelajaran jarak jauh. Selain itu, model e-learning ini memanfaatkan pembelajaran via internet dalam kegiatan pembelajaran. Metode yang digunakan dalam penelitian ini adalah kualitatif dengan analisis deskriptif. Subjek penelitian adalah informan yang memberikan data penelitian melalui wawancara, observasi dan dokumen. Informan dalam penelitian ini adalah dosen Universitas Panca Sakti Bekasi. Informan ditentukan dengan teknik purposive sampling. Sedangkan analisis data yang digunakan dalam penelitian ini adalah analisis deskriptif. Hasil penelitian ini menemukan bahwa penggunaan web e-learning dengan Moodle dan tatap muka dengan zoom atau google meet telah banyak dilakukan oleh dosen dalam mengelola pembelajaran selama pandemi Covid- 19 . Sebanyak $80 \%$ pembicara menyatakan bahwa mereka menggunakan zoom, ini karena lebih mudah menerapkannya secara langsung, seperti mengajar kelas jarak dekat dan pribadi. Kemudian, sebanyak 55\% pengguna Google Meet, instruktur menyatakan bahwa Google Meet tidak sulit untuk dibuat karena video tersebut langsung berjalan ketika sudah memiliki akun Google Mail secara langsung. Terakhir, sebanyak 85\% guru menggunakan Moodle, karena Moodle lebh memiliki fitur dalam kegiatan pembelajaran
\end{abstract}

Kata kunci: e-learning; Google Meet; Moodle; Zoom

\section{INTRODUCTION}

Coronavirus 19 pandemic or known as Covid-19 has been taking place in Indonesia since January 2020 (Ellyvon, n.d.). It is pandemic all through the world, remembering for Indonesia, has brought new issues. It isn't just a medical problem, yet in addition stretches out to political, financial, sociosocial and all parts of life. Various actions have been taken to prevent the spread of the virus that can cause respiratory problems (Rupita, 2020). One of them is by implementing large-scale social restrictions (PSBB/ Pembatasan Sosial Berskala Besar). This policy certainly has an impact on various fields, one of which is the field of education. In addition, the Ministry of Education and Culture (Kemendikbud) emphasized that the permit for face-to-face learning activities in colleges and polytechnics / community academies in the even semester of the Academic Year 2020/2021 can be carried out in a hybrid, networked, and face-to-face manner, with appropriate health strict protocols (Kemendikbud, n.d.). 
This pandemic forces to change massive and rapid in the application of a learning model. It does not require face-to-face learning in a classroom. An academic institution must apply distance learning (PJJ/Pembelajaran Jarak Jauh). Thus, learning strategies, methods, and approaches must be adapted to distance learning needs and styles.

Various kinds of problems and challenges arise in the application of distance learning, such as a lack of technological literacy for students, teachers, and parents (Fikri, Zaki Ananda, Faizah, Rahmani, \& Adelia Elian, n.d.). The unequal access to technology such as cellular networks in rural areas adds to the challenges that must be faced in PJJ. A type of methodicallly coordinated free learning in which advising, introduction of learning material, and managing and observing understudy learning achievement are done by a gathering of showing staff who have various duties. Learning is done distantly utilizing the assistance of the media.

Something contrary to the distance training framework is immediate or vis-à-vis schooling, a learning framework that happens as a result of direct contact among instructors and students. For this reason, the government, through the ministry of education and culture, launched a movement to help people who are struggling with the "Learning from Home" movement (Kemendikbud, 2020). A variety of activities and policies, and programs are designed to make this movement a success, including learning together through TVRI (Indonesia Government Television), which broadcasts educational shows for students. There are also policies related to emergency curricula that reduce the burden and basic competencies that students must complete while attending school.

Simonson (2014) explains that distance learning is formal education organized by an institution or institution where teachers and students are in separate places and uses an interactive communication technology system to connect students, teaching materials, and teachers. In the midst of a pandemic like this, distance education is the option chosen by almost all education actors (Kusuma \& Hamidah, 2020).

Distance learning focuses on using and utilizing information technology with gadgets to connect students with their teachers (Pakpahan \& Fitriani, n.d.). One of the different characteristics of distance learning from conventional learning is the learning center, which if conventional learning tends to be teacher-centered,

One of the learning approaches that can be implemented in order to support distance learning is the blended-learning approach or mixed learning which is an integration of face-to-face and online learning (Dziuban, Graham, Moskal, Norberg, \& Sicilia, n.d.). The application of e-learning can also improve student outcomes and satisfaction. E-learning is a generally new data innovation in Indonesia. (Kusmana, 2011) E-learning comprises two sections, to be specific 'e', which means 'electronic' and 'realizing', signifying 'learning'. So e-learning implies getting the hang of utilizing electronic gadget help administrations, especially computer devices. Along these lines, e-learning is frequently alluded to as 'online courses.' e-learning can urge students to look for data, assess it, share it cooperatively and, eventually, change it into their own insight (Dawley, 2007).

E-learning (Tîrziu \& Vrabie, 2015) is exceptionally valuable for students in getting the hang of learning materials in light of the fact that with this innovation they can adapt deftly any place and at whatever point required. Material that isn't perceived by students at school can be relearned through e-realizing so it will make it simpler for students to comprehend the material with additional time since it isn't restricted like in school.

E-learning has happened to expanding significance for different reasons, for example, the ascent of data and worldwide economy and the development of a buyer culture. Students of the 21 st century request an adaptable construction that permits them to study, work and take part in everyday life simultaneously. This adaptability is reflected in elective conveyance techniques that incorporate Internet use .

The meaning of e-learning is extremely different, e-learning is a learning framework that can help learning exercises by using electronic media. This definition centers around the thought of e-learning in a learning framework that uses the utilization of electronic media.

The advantages of E-learning are: 1) Flexible. E-learning gives adaptability in picking the time and spot to get to learning. 2) Independent Learning. E-learning gives freedoms to students to autonomously assume responsibility for learning achievement. 3) Cost Efficiency. E-learning gives cost effectiveness to managers, proficiency in the arrangement of actual offices for learning and cost productivity for students is the expense of transportation and convenience (Hayati, 2020).

In particular, Panca Sakti Bekasi University lecturers applied E-learning during this pandemic by using zoom and google meet and moodle to manage learning activities.

E-learning at this university uses Zoom, which can be achieved by using learning media in the learning process in any situation and conditions 
in terms of the material content or the student environment's state. Thus, a concept to students will be conveyed by the effectiveness of Using the Zoom application as an online learning media for students during the covid 19 pandemic (Monica \& Fitriawati, 2020). The worldwide pandemic of COVID-19 has turned the focus on video conferencing applications more than ever. In this crucial time, applications, for example, Zoom have encountered a flood in its client base hop over the 300 million every day mark (“Zoom Blog," n.d.).

Zoom's use for education is also very applicable (Lessons, 2020)

1. For your top notch, put to the side some an ideal opportunity to acquaint your students with Zoom furthermore, guarantee that they're ready to interface their sound and video.

2. Give a plan or plan for each class by Screen Sharing an archive or slide toward the start of class. This gives students an unmistakable thought of how the class will advance, what will be covered, and the exercises they'll take part in.

3. Discuss online manners and assumptions for the students in your first virtual class and intermittently return to the themes.

4. Utilize the Whiteboard or Annotate a common record and let your students connect also. When sharing a whiteboard, archive, screen, or picture, have a go at whiteboarding numerical statements or have an understudy use explanation to feature things, for example, language structure botches in a paper you're sharing.

5. Take time to advance inquiries, remarks, and responses from your group. Give a moment to permit your students to use responses, compose their inquiries in talk, or be unmuted to pose their inquiries live.

6. Divide into more modest gatherings for a conversation on a specific subject. You can utilize Zoom's Breakout Room highlight to by the same token pre-allot or auto-relegate students into bunches for a brief timeframe so they may talk about things together.

7. Have students be the moderator and offer tasks with the class. This permits your students to show what they'reworking on while rehearsing their introduction abilities. It additionally permits students to hear from each other.

Some of the factors that influence the effectiveness of e-learning are experience and expertise in using the internet and computer applications. Both of these factors affect both teachers and students (Picciano \& Seaman, 2007). The higher the time to use the internet, as well as the understanding of using existing applications, the better the teacher will be in increasing the effectiveness of e-learning. In addition, Zoom is an application that gives distant conferencing administrations by consolidating video conferencing, online gatherings, talk, and versatile coordinated effort.

The previous research of zoom from Rahmatia, \& Syahira (2020) stated that the effectiveness of using zoom in learning In view of the poll information, $100 \%$ of students said that they comprehend the utilization of zoom gatherings. As numerous as $70 \%$ of students expressed that the conveyance of material utilizing zoom was clear, implying that the other $30 \%$ said the material was not obviously noticeable on the zoom application. While $70 \%$ of students said that the zoom media was successfully utilized, the excess $30 \%$ said it was insufficient.

Beside that, google meet is an alternative application for video conferencing. Where students and writers as lecturers teaching courses practice the Google Meet application by working from home (Sawitri, 2020). Google Meet has an interesting and useful interface or interface with a light and quick size by focusing on friendly productive and easy use.

Google Meet (Wiratama, 2020) can be connected by opening Google Chrome and signing in through email. Google Meet can be gotten to through the site, Android or iOS. The google meet application has a very decent help quality. Google Meet can oblige 250 individuals in each video chat. Talks utilizing google meets, the instructor can see understudy study archives as well as make introductions, show materials, and record them. (Septantiningtyas et al., 2021) The Google Meet application impacts students' learning revenue, this is on the grounds that the student is extremely simple to carry out, adaptable time and can be carried out at where every understudy is found. In the learning cycle in addresses, students turn on the video with the goal that the speaker can handle the presence and exercises of students, the learning climate looks like in the study hall. Thus, according to Septantiningtyas (2021) the Google meet application affects understudy revenue in learning this is on the grounds that the student is not difficult to carry out, time is adaptable and can be executed where every student is found.

The results of subsequent research via google form was proved by (2021), it very well may be finished up generally speaking that picking up utilizing the Google Meet application impacts students' learning interest, this is on the grounds that the student is not difficult to execute, adaptable time and can be carried out at where every student is found. 
Next, using moodle is an online framework for learning management intended for the management of educational and interactive environments. In such forums, educators. This is because of the great collection of decisions with respect to explicit errands and to test plan choices accessible in Moodle (Fernando, 2020).

(Moodle, n.d.) Moodle for Education OpenSource Learning for Various Ventures and Needs As innovation's part in the public arena in general keeps on advancing, an adaptable Learning Management System is basic to addressing the necessities of the present current student. Moodle gives a focal learning center to associate eLearning instruments and improve on the instructing and learning measure. With its usefulness and module capacities, Moodle offers a drawing in and compelling eLearning experience for students, all things considered. Moodle takes into account extraordinary learning strategies like gamification, competency-based instruction, portable learning, available gradebooks, intelligent online homerooms, and significantly more.

Furthermore, because of its innate adaptability and simple to-utilize interface, Moodle can be utilized to arrive at a wide scope of necessities. Truth be told, numerous students that are acquainted with Moodle in essential, optional, and advanced education end up utilizing Moodle again further down the road when they enter the labor force, which we'll investigate in the following segment. All things considered, Moodle has the additional advantage of giving simple adaption to the two teachers and students who may have encountered the stage somewhere else already.

They are exposed to a wide variety of tools, ideas and experiences that enable them to understand the teaching principles available and to broaden their awareness of opportunities to alter or strengthen, thereby contributing to their professional growth (Pereira de Brito \& Martinho, 2018). (Lisnani, Putri, Zulkardi, \& Somakim, 2020) The fiturs of Moodle consit administrator/scientists' highlights which comprise of master surveys or remarks and methods of gathering information. Also, it very well may be the support of the entrance of Moodle for instance login and log off the Moodle. Besides, guardians' highlights purposes to encourage guardians to examine with educators through conversation highlights. They could talk about the states of their kids. The highlights comprise of students' scores, tests, and reports, to control their scholastic expanding.

The previous research of positive effect by using moodle from Ahmad and Al-Khanjari (2012) varied choices offered in Moodle, like assignment submissioeffern, messaging, category notices, attendance, session plans, educational calendars, category notes might influence absolutely. so that they were positive concerning E-learning and felt that availableness of teaching materials, calendars etc. Thus, all of the features are extra positive options of in Moodle.

Thus, Along with the Covid pandemic, the use of e-learning media must be used as effectively as possible, so that learning activities can continue. Based on the above phenomena, the purpose of this study is to determine the extent of the use of e-learning media such as google meet, zoom and Moodle by lecturers at Panca Sakti University, Bekasi.

Finally, there are several measures to assess the quality of scientific papers, as follows: (1) the novelty in this study shows that of the three platforms such as Zoom, Google meet and Moodle, the most effective is zoom. This is due to the practicality and face-toface atmosphere that is accommodated in Zoom. (2) Contributions in this study can provide important information that the use of zoom can be further maximized in lecture learning activities.

\section{METHOD}

The author uses a qualitative approach and literature study technique with descriptive-qualitative analysis information obtained through numerous relevant sources and references similarly as connected scientific studies. The phrases qualitative studies and descriptive studies are from time to time used interchangeably which contain naturalistic statistics to examine language studying and coaching of their evidently happening settings with none intervention or manipulation of variables (Bryman, 2008).

The purpose of this descriptive research is to make a description, a systematic, factual and accurate description of facts, properties and relationships between phenomena investigated. (Ayiro, 2012) this book tries to utilize outcomes of research for the benefit of humanity. The text examines how research is conducted across the major traditions of educational research (quantitative, qualitative, and mixed methods Engaging descriptive exploration is focused on: (1) gathering genuine data in detail portraying existing side effects, (2) recognizing issues or inspecting past conditions and practices, (3) making examinations or assessments, (4) figuring out the thing individuals are doing others deal with similar issues and gain from their encounters to set likely arrangements and choices.

Then, qualitative analysis methodology is a analysis that's accustomed examine natural objects 
wherever the researcher is that the key instrument, knowledge analysis is inductive, and therefore the results of qualitative analysis emphasize meanings instead of generalization (Strauss, 2010). The information assortment procedures utilized are: a) writing concentrate by gathering different information from writing from online news, logical diaries and books; b) field study, specifically the writer goes to the field to acquire information and data. Extensively, qualitative examination is by and large utilized to help a scientist in creating a profound and nuanced comprehension of a given phenomenon. It is on the grounds that the goal of abstract examination is to portray social wonders in a naturalistic characteristic way (Creswell \& Creswell, 2020).

In other words, A qualitative approach is an comprehensive approach or strategy for locating or getting the specified information. An approach is a method, principle, and procedure that we have a tendency to use to approach issues and notice answers (Flick, 2019). The approach is influenced or supported the theoretical perspective that we have a tendency to use for conduct analysis, whereas the theoretical perspective itself may be a framework of clarification or interpretation that allows researchers to know information and connect sophisticated information with alternative events and things.

In this research, the informantss used purposeful sampling techniques, namely the technique of evaluating informants on the basis of certain parameters or considerations (Sataloff, Johns, \& Kost, n.d.). The first criterion for the selection of Informantss in this study is that the Informants must make use of learning media such as zoom, google meeting, and Moodle by lecturers from Panca Sakti University Bekasi. There were research interviews performed to lectures at Panca Sakti Bekasi University.

\section{RESULTS AND DISCUSSION}

The information that has been accumulated might be processed and information processing is executed through triangulation, reduction, presentation of information, drawing conclusions (Creswell, 2014).

1. Triangulation. Triangulation is a method for checking the validity of information which uses some thing aside from information as a evaluation to those information.

There are 3 varieties of triangulation, specifically triangulation with source, triangulation through technique, and triangulation time. In this article, the authors used triangulation the use of sources, specifically through how to test the information received via several source.

In this study, to test credibility e-learning media utilization data, then the data obtained tested to the lecturer who is the subject of research and adapted to the theory - existing theory.

2. Reduction. Reduction is summarizing, choosing the principle things, and awareness at the essential things. With so, the decreased information will give a clearer picture. In this studies, Researchers centered on using e-getting to know media performed through lecturers

3. Presentation of Data After. The information is decreased, the following step is gift information. Data is supplied in textual content form that's narrative. Data supplied with organization in step with their respective sub-chapters - respectively.

4. Conclusion Withdrawal. After the information is supplied, the following step is drawing conclusions. After describing various the information that has been received, the researcher makes the end result of a studies.

Researchers collect data through observation or observation, interview and documentation study, then administered a descriptive analysis of utilization of e-learning media at Panca Sakti University Bekasi. Inner object This research is using zoom, google meet and Moodle. the situation of this research is at Panca Sakti University Bekasi.

The author conducted an analysis to work out focus research before doing research. The results obtained from the analysis before the sector are lecturers make use of the training media provided by service provider platforms like Google Meet, Zoom and Moodle.

The criteria for informants in this study are lecturers who utilize elearning media such as zoom, google meet and Moodle at Panca Sakti University Bekasi. Apart from this, the researchers interviewed 18 lecturers representing the nine study programs managing learning media using the platform and its benefits. ("PDDikti - Pangkalan Data Pendidikan Tinggi," n.d.)

Tabel 1. Faculty Name and Number of Informantss

\begin{tabular}{clc}
\hline No & \multicolumn{1}{c}{ Faculty Names } & $\begin{array}{c}\text { Number of } \\
\text { Informants }\end{array}$ \\
\hline 1 & $\begin{array}{l}\text { S1 Early Childhood education teacher } \\
\text { education }\end{array}$ & 61 \\
2 & S1 Economics education & 31 \\
3 & S1 English education & 22 \\
4 & S1 Management & 13 \\
5 & S1 Accounting & 11 \\
6 & D3 Computerized accounting & 5 \\
7 & D3 Information Management & 6 \\
8 & S1 Informatics Engineering & 10 \\
9 & S1 Informatics system & 8 \\
\hline \multicolumn{2}{c}{ Numbers }
\end{tabular}


The table above is the names of the faculties and the number of lecturers at Panca Sakti University, Bekasi. The number of lecturers above are informantss who answered interview questions regarding the use of Zoom, Google Form and Moodle

Tabel 2. Lecturer who have ever and never used zoom, google form and moodle

\begin{tabular}{clcc}
\hline No & \multicolumn{1}{c}{ Platform } & Ever & Never \\
\hline 1 & Zoom & $100 \%$ & $0 \%$ \\
2 & Google meet & $60 \%$ & $40 \%$ \\
3 & Moodle & $85 \%$ & $15 \%$ \\
\hline
\end{tabular}

Based on the data above, that $100 \%$ of lecturers use zoom to deliver face-to-face lectures. Next, as many as $60 \%$ of lecturers use google meet and $85 \%$ Moodle for class management. Therefore, it can be concluded that face-to-face lecturers use more zoom, while class management uses Moodle ore.

Reasons for Informantss to Use Zoom, Google Meet and Moodle.

\section{Zoom}

It has a huge space limit. The Zoom Cloud meeting application can oblige up to 1,000 members and 10,000 watchers in a gathering. With this huge number of members, zoom has a decent administration for holding on the web gatherings with the most members.

Having the best video and sound quality, the benefits of Zoom Cloud Meeting are having the option to introduce clear video quality and clear solid with the goal that it will be simpler when conveying.

There are different showing teaching tools like white board and to planning on the web gatherings. These highlights may just be accessible in the Zoom application.

Supporting lectures introductions who need to clarify or comprehend a material all the more profoundly. In the Zoom Cloud Meeting application you can introduce material records to different members. The two members and moderators can jot on the introduction with the goal that it will make it simpler to extend the material.

There is a video on/off element. In the event of a gathering you presently don't require your face and voice to show up, at that point you can set video and sound to kill. This favorable position, obviously, will keep up your protection without upsetting the course of a gathering.

It is accessible on a wide assortment of gadgets. For those of you who just have a cellphone, don't stress. This is on the grounds that the Zoom Cloud Meeting application can be run on different gadgets including Android, iPhones, PCs, or workstations.

\section{Google Meet}

There are some upsides of Google Meet. The presence of new administrations surely brings new highlights and favorable circumstances that can help speakers. Instructors can complicatedly use on the system.

Moreover, it $\mathrm{v}$ may be utilized in any working framework from work area, Android or iOS. Aside from the above mentioned, the combination of Google Calendar with Google Meet will make it simpler to direct online gatherings. With this assistance, clients can settle on a single tick meeting decisions as indicated by a predefined plan. The following bit of theutilization of screens can be adapted to introduction needs, sharing archives or book keeping pages.

\section{Moodle}

Lectures expressed the upsides of the Moodle learning stage that Moodle should know is reasonable for application in online classes. During on the web classes can give learning on Moodle gadgets that can be gotten to by anybody. Moodle gives different dialects to its clients. Every client can utilize the language they need.

Moodle is Open Source programming, otherwise known as free and effectively open to anybody. Moodle has client the board, ordinarily known as course the executives, evolving courses, deducting, and adding course types. Gives a visit bot module, diary module, test module, review module, workshop, surveying and numerous different modules.

It is basic, viable, lightweight and productive platform. Those are the favorable circumstances controlled by the Moodle learning stage. Teachers are additionally keen on utilizing moodle in learning. Simply use Moodle, in light of the fact that it can make it simpler for us to instruct.

Tabel 3. Lecturer opinion on the effectiveness of using e-learning media

\begin{tabular}{llll}
\hline No & \multicolumn{1}{c}{ Platform } & Ever & \multicolumn{1}{c}{ Never } \\
\hline 1 & Zoom & $80 \%$ & $20 \%$ \\
2 & Google meet & $55 \%$ & $45 \%$ \\
3 & Moodle & $85 \%$ & $15 \%$ \\
\hline
\end{tabular}

Based on the survey results above, as many as $80 \%$ of lecturers stated that they used zoom because it was easier to apply it directly, such as teaching faceto-face classes. Then, as many as $55 \%$ of Google Meet users, the lecturer stated that Google Meet is easy to implement because the video is directly connected if you already have a Google Mail account directly. And finally, as many as $85 \%$ of lecturers use Moodle, because Moodle provides more features for learning activities. 
In addition, the results showed that students who participated in online learning using the Zoom Meeting platform achieved better use in learning activities than lecturers who used the Google Classroom and Moodle platforms. This is because learning using Zoom Meeting is easier to understand because the explanation of the material is done directly, the discussion is more flexible and the response is faster than using Google Classroom and Moodle. This finding also shows that online learning with a synchronous format is more profitable than asynchronous

\section{CONCLUSION}

Thisexplorationis anengagingsubjectiveexamination that means to characterize and portray the e-learning usage that is described in utilizing an electronic web framework that supports learning exercises. The technique utilized in this research is subjective with engaging investigation. Exploration subjects are Informantss who give research information through meetings, perception, and records. The Informantss in this investigation were speakers at Panca Sakti Bekasi University. The Informantss were dictated by purposive examining procedure. Simultaneously, the information investigation utilized in this examination is elucidating. This examination brings about the finding that speakers have done web e-learning with Moodle and eye to eye with zoom or google meet in overseeing picking up during the Covid-19 pandemic. Thus, the results say as various as $80 \%$ of speakers communicated that they used zoom, this was because it was less difficult to apply it clearly, such as training very close classes. By then, as various as $55 \%$ of Google Meet used by lectures. The educator communicated that Google Meet isn't hard to realize because the video is direct related if you as of now have a Google Mail account clearly. Ultimately, as various as $85 \%$ of instructors use Moodle, because Moodle gives more features to learning works out. Lastly, this research showed that students who participated in online learning using the Zoom Meeting platform achieved better use in learning activities than lecturers who used the Google Classroom and Moodle platforms. This is because learning using Zoom Meeting is easier to understand because the explanation of the material is done directly, the discussion is more flexible and the response is faster than using Google Classroom and Moodle. This finding also shows that online learning with a synchronous format is more profitable than asynchronous

\section{REFERENCES}

Ahmad, N. \& Al-Khanjari, Z. (2012). Effect of Moodle on learning: An Oman perception.
International Journal of Digital Information and Wireless Communications (IJDIWC), 4, 782-788.

Ayiro, L.P. (2012). A functional approach to educational research methods and statistics: qualitative, quantitative, and mixed methods approaches. Retrieved from http://public.eblib. com/choice/publicfullrecord.aspx?p=997330

Bryman, A. (2008). Social research methods. Oxford; New York: Oxford University Press.

Creswell, J.W. (2014). Proceedings of the Annual Conference of the International Speech Communication Association, INTERSPEECH. Proceedings of the Annual Conference of the International Speech Communication Association, INTERSPEECH.

Creswell, J.W. \& Creswell, J.D. (2020). Research design: qualitative, quantitative, and mixed methods approaches.

Dawley, L. (2007). The tools for successful online teaching. Hershey (PA): Information Science Publishing.

Dziuban, C., Graham, C.R., Moskal, P.D., Norberg, A., \& Sicilia, N. (n.d.). Blended learning: the new normal and emerging technologies. https://doi. org/10.1186/s41239-017-0087-5

Ellyvon, P.(n.d.). Diumumkan Awal Maret, Ahli: Virus CoronaMasukIndonesia dari Januari. Retrieved February 15, 2021, from https://www.kompas. com/sains/read/2020/05/11/130600623/ diumumkan-awal-maret-ahli--virus-coronamasuk-indonesia-dari-januari

Fernando, W. (2020). Moodle quizzes and their usability for formative assessment of academic writing. Assessing Writing, 46, 100485. https:// doi.org/10.1016/j.asw.2020.100485

Fikri, M., Zaki Ananda, M., Faizah, N., Rahmani, R., \& Adelia Elian, S. (n.d.). Kendala Dalam Pembelajaran Jarak Jauh Di Masa Pandemi Covid-19: Sebuah Kajian Kritis. https://doi. org/10.1016/jjheduc.2013.06.00

Flick, U. (2019). An introduction to qualitative research.

Hayati, N. (2020). Metode Pembelajaran Daring/ELearning Yang Efektif A. Pendahuluan Sejarah Elearning.

Kemendikbud. (n.d.). Kementerian Pendidikan dan Kebudayaan » Republik Indonesia. Retrieved October 29, 2020, from https:// 
www.kemdikbud.go.id/main/blog/2020/05/ kemendikbud-terbitkan-pedomanpenyelenggaraan-belajar-dari-rumah

Kusmana, A. (2011). E-Learning Dalam Pembelajaran. Lentera Pendidikan: Jurnal Ilmu Tarbiyah Dan Keguruan, 14(1), 35-51. https://doi.org/10.24252/lp.2011v14n1a3

Lessons, V. (2020). Tips \& Tricks : Teachers Educating on Zoom. (March), 1-2. Retrieved from https:// zoom.us/docs/doc/Tips and Tricks for Teachers Educating on Zoom.pdf

Lisnani, L., Putri, R. I. I., Zulkardi. \& Somakim. (2020). DesigningMoodle features ase-learning for learning mathematics in COVID-19 pandemic. Journal of Physics: Conference Series, 1657, $12024 . \quad$ https://doi.org/10.1088/17426596/1657/1/012024

Monica, J. \& Fitriawati, D. (2020). Efektivitas Penggunaan Aplikasi Zoom Sebagai Media Pembelajaran Online Pada Mahasiswa Saat Pandemi Covid-19. Jurnal Communio : Jurnal Jurusan Ilmu Komunikasi, 9(2), 1630-1640. https://doi.org/10.35508/JIKOM.V9I2.2416

Moodle, T. C. (n.d.). What is Contents.

Pakpahan, R. \& Fitriani, Y. (n.d.). JISAMAR (Journal of Information System, Applied, Management, Accounting and Researh). Retrieved from http://journal.stmikjayakarta.ac.id/index.php/ jisamarTelp.+62-21-3905050

PDDikti - Pangkalan Data Pendidikan Tinggi. (n.d.). Retrieved March 26, 2021, from https://pddikti.kemdikbud.go.id/data_pt/ jY3LUEwQUItNDYwMDQwRDE4RjdF

Pereira de Brito, L. \& Martinho, M.H. (2018). Fostering teachers' adoption of moodle: An action-research framed on evolutionary game theory. Journal of E-Learning and Knowledge Society, 14(3), 17-28. https://doi. org/10.20368/1971-8829/1443

Picciano, A.G., \& Seaman, J. (2007). A Survey of U.S. School District Administrators K-12 Online Learning: A Survey Of U.s. School District Administrators.

Rahmatia, \& Syahira. (2020). The Student Perspectives on the Effectiveness ofMedia
Zoom Meeting in Increasing Knowledge of Thesis Writing at STKIP Muhammadiyah Manokwari. International Journal of Education Information, 3(2), 333-337. https:// doi.org/10.5281/zenodo.3987204

Rupita. (2020). Community Empowerment As A Form Of Community Social Resilience Facing The Impact Of Covid-19. Sosiohumaniora; 22, (3), 348-355.

Sataloff, R. T., Johns, M. M., \& Kost, K. M. (n.d.). Encyclopedia of Survey Research Methods.

Sawitri, D. (2020). Penggunaan Google Meet Untuk Work From Home DiEra Pandemi Coronavirus Disease 2019 (Covid-19). Prioritas: Jurnal Pengabdian Kepada Masyarakat, 2(01), 1321. Retrieved from https://jurnal.harapan.ac.id/ index.php/Prioritas/article/view/161

Septantiningtyas, N., Juhji, J., Sutarman, A., Rahman, A., Sa'adah, N. \& Nawisa. (2021). Implementation of Google Meet Application in the Learning of Basic Science in the Covid-19 Pandemic Period of Student Learning Interests. Journal of Physics: Conference Series, 1779(1), 12068. https://doi.org/10.1088/17426596/1779/1/012068

Simonson, M.R., Smaldino, S.E. \& Zvacek, S. (2014). Teaching and learning at a distance: foundations of distance education. Retrieved from https://search.ebscohost.com/login. ssite $\& d b=$ nlebk $\& d b=$ nlabk $\& A N=844929$

Strauss, A. L. (2010). Qualitative Analysis for Social Scientists. Cambridge, GBR: Cambridge University Press. Retrieved from http:// public.ebookcentral.proquest.com/choice/ publicfullrecord.aspx? $\mathrm{p}=4640021$

Tîrziu, A.-M., \& Vrabie, C. (2015). Education 2.0: E-Learning Methods. Procedia - Social and Behavioral Sciences, 186, 376-380. https://doi. org/10.1016/j.sbspro.2015.04.213

Wiratama, N. A. (2020). Penerapan Google Meet Dalam Perkuliahan Daring Mahasiswa PGSD Pada Mata Kuliah Konsep Dasar PKN SD Saat Pandemi COVID 19. Jtiee, 4(2), 1-8.

Zoom Blog. (n.d.). Retrieved March 16, 2021, from https://blog.zoom.us/ 